\title{
You, Me and the Housework
}

\author{
Discussion of the 'Housewife film's Compère
}

\author{
Anne Marit Myrstad
}

Throughout media history, several genres have emerged as an answer to the trading industry's need to reach women as consumers. Soap operas and "woman's films" are among the most distinct and discussed in this respect. In the 'public service' countries Norway and Sweden, a particular type of film, known as "Housewife film", was developed in the 1950s and produced for the next few decades. The hour-long "Housewife film" consisted of a row of long commercials providing information about, and education in, the use of new foodstuffs and household technologies. In addition, breaks between these informative commercials featured entertainment from the nation's leading comedians. These entertainers had the role of host (or compère), whose performances tied the row of commercials together.

This article focuses on communicative strategies connected to the compère of the first Norwegian Housewife film. The work connects to a broader study of the Norwegian Housewife films 'That's how to do it': Housewife film as Popular Culture', a project that itself is part of an interdisciplinary project focusing on housework in the Twentieth century. ${ }^{1}$ The project on Housewife films discusses this group of films as rhetorical genre, and as an arena for negotiating gender boundaries during the peak and decline of "the good housewife period". In Norway, Housewife films were produced between 1953 and 1972. The films can be regarded as part of an aggressive campaign aimed at informing and educating housewives throughout the Western world.

The available source material suggests that the Housewife films, which were seen primarily in separate, free-of-charge daytime screenings in cinemas all over the country, drew crowds for a long time, and peaked in the second half of the 1960s. When Informasjonsfilm $A / S$ - the main production company behind these films for the Norwegian market - decided to terminate production in 1972, their decision was based on the films' declining popularity and the increasing societal pressure on the housewife as social role. The production of Housewife films had been highly profitable and functioned as the company's financial backbone. Information films for the expanding Norwegian oil industry took over this position within the company and thus replaced the production of Housewife films. ${ }^{2}$

The Housewife film seems to have been developed in Sweden when the production company Husmorfilm AB was established in 1952 by film worker Bengt Davidsson in cooperation with Elsa Lindstrøm from the leading Swedish research institute on household 
development, Hemmens Forskningsinstitut. Davidsson, who was interested in using cinemas in the daytime, had already produced some long commercials directed towards housewives. His cooperation with Lindstrøm seems to have been established as a response to the fact that these first long commercials of Davidsson were faced with criticism and Hemmens Forskningsinstitut was among the critics. The institute claimed that housewives could be manipulated by this type of hour-long advertising films. Davidssons solution was to develop, through collaboration with Lindstrøm, the format into a hybrid of information and advertising in which the home economics expert played a vital role. She would assist in script development and ensure that the information given in the film was reliable, ethical and in line with the newest research and well-established household 'know-how'. (Jansson 1996:7). The Norwegian Housewife films were based on - and closely connected to - this new, hybrid Swedish format. The Norwegian films were produced, annually at first and from 1962, every spring and autumn. Production of Housewife films in Norway seems to have been initiated by two Norwegian companies Lilleborg fabrikker (soap) and Margarincentralen (butter). They communicated with the Swedish advertising industry in 1952 due to weaknesses within Norwegian production of commercial films at the time. ${ }^{3}$

Regular cinema commercials are, as we all know, advertisement presented in connection with feature films for a paying audience. Conversely, the Housewife films were offered free to the public, but without the feature film to attract an audience. The Housewife films were, on the other hand, assisted by social and cultural attractions. The screenings included handing out brochures and samples, and local shopkeepers marketed the films in advance and were called on to offer the products promoted in the films. In larger towns the film screenings were encouraged through fashion shows. The ethos appeal creating goodwill through entertaining and confidence-inspiring strategies - came to characterize the films as well as the screenings. ${ }^{4}$

Housewife films were commercials, financially speaking, and in this respect a form of joint advertising. The joint advertising emphasized entertainment, on the one hand, and education, on the other. The entertaining breaks between commercials, in which the compère explicitly establishes a relationship with the audience leading them through the didactic commercials, are critical to the format in this respect. These breaks frame the row of commercials rhetorically. The compères were often successful actors in the entertainment business and had amused large audiences previously through stage, screen and radio performances. From the beginning, the host was a man, sometimes accompanied by a woman. Wenche Foss, a Norwegian theatre and film diva, is the first and - as my current research indicates - the only woman who played this part alone and then in the 1967 film Gjør det lettere (Make it simpler). ${ }^{5}$

Advertisers paid for, and followed up on, individual commercials throughout the production process. To establish the necessary confidence in the films, the production company, as already mentioned, hired household expertise; Ingerid Askevold, Manager of Statens opplysningskontor for husstell (National Information Bureau for Domestic Science), Home Economics Educationalist Ingrid Espelid, ${ }^{6}$ and chefs like Ben Josef and Hroar Dege. These experts contributed to the films argumentation and mode and also actively participated in test screenings for the advertisers.

According to one of the household experts in the Swedish films, the entertaining breaks between commercials were, to a large extent, the film companies' domain (Jansson 1996). In this area, knowledge about film and how to communicate to housewives as target group was most important. The Norwegian film worker Terje Helweg states that, throughout his work in Norwegian Housewife film production, the entertain- 
ing breaks were always planned exclusively by the principal film director Jan Erik Düring ${ }^{7}$. This could indicate that Düring, as the creative head of the team, was fully aware of the significance of the entertaining breaks for the audiences' acceptance of the films, but also that he regarded this part of the work as a professional challenge. The goodnatured and humorous communication during the entertaining breaks might have taken the sting out of the didactic and more authoritative tone of the informative commercials.

\section{Compère $^{8}$ in an Armchair}

The role of the compère - as it was shaped by the already celebrated actor Per Aabel in the two first Housewife films involves meeting a celebrity who presents himself and, at the same time, functions as the housewives' male girlfriend. The first scene of Slik kan det gjøres (That's how to do it) from 1953 demonstrates considerable persuasive power. In order to build a light and comfortable setting, Aabel does not appear as a lecturer, an expert, or a distinct authority. Humour and closeness to the audience are created through dialogue and directing in order to arouse curiosity and interest. Aabel puts on display the household technology, the housework, the housewife, and himself.

\section{- Progress and Pessimism from the World of Art}

The film's introductory titles are accompanied by grand, sweeping music reminiscent of light entertainment: the vaudeville as well as film and radio comedy of the day. The last introductory title in the film states that Per Aabel is the film's compère. While the music fades away, the camera focuses heavily on Aabel's name on an open book: Aabel's autobiography Du verden! (Blimey!). The camera zooms out and Aabel, reading the book, appears in the shot as he is putting down the book. He addresses the camera by saying, "Blimey - how things have changed! How technology is developing these day - with huge steps!"9 In line with the rhetorical rules for opening a speech, goodwill is aroused by focusing on the speaker. ${ }^{10}$ While getting up from his armchair and placing the book on the bookshelf, Aabel continues speaking directly into the camera, maintaining eye-contact with the audience, and giving examples of the technical novelties that have affected his own work as an actor. Aabel speaks ironically about both the tape recorder and film images that are supposedly helpful, but primarily show the performer his mistakes and shortcomings. In this way, he can occasionally add, mockingly, "Blimey, what progress!"

We meet the compère as a relaxed, famous artist expressing scepticism towards all these novelties. Whether these new products are really "progress" is questionable to Aabel. Facing resistance aggressively is a tactic of eulogistic, or epideictic, rhetoric. Even though public debate in the 1950s was predominantly optimistic about the future, this "speech," addressed to housewives, takes into consideration that women's role as keepers of tradition included a certain amount of scepticism towards novelty. The mother's and housewife's task was to protect and pass on traditional values and customs to the next generation. The fact that housewives could be sceptical towards technological novelties was probable and commonly known. Recognising technological scepticism not household technology - in this case, can be interpreted as a strategy to win the housewives' trust and confidence. By expressing scepticism towards technology, arguments that questioned the utility value of technology are refuted and goodwill based on a now shared technological scepticism is simultaneously created.

Confidence may be a reward in this instance precisely because Aabel advocated a view that in 1953 was not publicly recognised, or expected, when industry gave infor- 
mation about new products. Drawbacks of the novelties could be interpreted as something Aabel discusses exclusively with the housewives. While commercials aimed at a mixed audience had to strictly consider community values, commercials oriented towards target groups, like the Housewife film, could appeal to attitudes and views expected within this specific audience, even if they did not have wider public support. Should anyone in the audience not share Aabel's scepticism towards new technology, she could always take pleasure in his attack on new appliances as an intimate confidential statement from an eccentric artist and celebrity. Aabel is allowed to perform as the person the audience knows: a reputable actor. He does not represent the advertisers straight on. He is the "mediating body"11 on the products' way to the consumers.

Confidence and intimacy are also created in the first moments through the absence of music when Aabel begins to speak, his informal style in addressing the audience without opening phrases such as "Ladies and gentlemen," the close-up of his face, his eyecontact with the audience, and his casual and unceremonious way of sitting in his chair. Furthermore, it is understood that the scene depicts his private home, a fact that intensifies the close and intimate atmosphere.

\section{- "The Man Who Kept House"12}

The sense of being in Aabel's home is strengthened when he begins to discuss housework. Aabel discovers a coffee cup and a sugar bowl on the dining room table. On his way into the kitchen, he complains about the amount of time he spends on the housework, "Oh, I wonder how many hours of my life I have spent on housework. I don't even dare to think about it. I don't dare!" He utters this line while maintaining eye-contact with the audience, approaches the camera, and is shown holding only one cup and one bowl. The scene is hilarious because the amount of housework he complains about is ridiculously small compared with the amount his audience of housewives may be expected to face every day. The fact that he complains about nothing is supported with his next line, which reveals he is a bachelor. However, the camera/audience is not invited into his bachelor kitchen. Deprecatingly, Aabel leaves the picture through the door leading into his kitchen. The frame is frozen while we hear rattling and breaking sounds coming from his kitchen. He reappears in the doorway and apologizes, "Oh, dear ... one cup less to clean, it wasn't worse!"

The intimacy of this sequence is further developed when the camera/audience is shut out from the kitchen. We have been allowed to follow him to, and overhear his activities in, the one place he himself describes as one of his most private rooms. Being forced to wait outside while he is rummaging in his kitchen gives the distinct impression of a "here and now" presence in Per Aabel's life. At the same time, the target audience's self-esteem is nurtured in this sequence. The audience of housewives can enjoy moments of self-satisfaction in knowing they are much more competent at cleaning, laundry and cooking, as they watch this clumsy, complaining bachelor. When he breaks the cup, this refers to the fairly tale of the conceited man trying unsuccessfully to take care of the house. Housework is heavy work, but housewives master it better than any bachelor - and men in general.

\section{- Housewife, but also a Woman}

The last sequence in this scene is meant to build towards the approaching commercial for The Modern Kitchen. As Aabel is watering his potted plants, humming a song about flowers, complaining about his old-fashioned kitchen and thinking about modernizing, 
his thoughts wander to his neighbour: "Speaking of flowers - down there lives a charming little housewife - named Mrs. Berg, I think. It is so strange how she has changed for the better over the past year. She actually looks younger and younger every time I see her." So far, Aabel has looked in turns at the audience and out of the window. He now delivers the scene's "punch line", "I wonder why!", fixing eye-contact and encouraging the audience to pay close attention to what comes next.

At this instance, it is no longer a matter of building up the housewives' self-image. On the contrary, it is a matter of challenging them. As a housewife, the spectator is not only a member of "Norway's largest occupational group," as the film's voice-over states in the next scene in line with the contemporary political discourse, but she is also a woman and should, according to social expectations, always attend to her "to-be-looked-at-ness". Housewives are at all times the object of men's, and woman's, scrutinizing attention. Focusing on physical appearance and standards of beauty appeals to the potentially wavering gender identity. At the same time as Aabel praises Mrs. Berg in a mild, wellintentioned voice, stronger emotions than those attached to the housewives' desire to make housework more efficient are roused. In this case, the ethos appeal borders on pathos through the appeal to strong emotions, psychologically speaking. The housewives are thus motivated to find out what caused the radical improvement in Mrs. Berg. Contrary to the course of nature, but in line with the advertising industry's promises to women, she looks younger and younger. Looking young and beautiful and, at the same time, maintaining and spreading happiness, is a housewife's main commitment. In this respect the Housewife film keeps up with traditional expectations for women in general. If, for example, a new appliance for the kitchen makes you look younger, this is a good, if unspoken, argument in favour of buying it.

The intensification of the rhetoric that lies in this sequence's potential destabilization of the spectators' self-esteem is followed up stylistically by clarifying that the compère is a representative for the audience. Earlier in the scene, Aabel prevented the camera from capturing the bachelor kitchen, and he now arouses the spectators' visual desire to look more closely at Mrs. Berg. By constantly throwing glances out of the window in her direction and out of the frame, the compère entices the spectator further into the miseen-scene and story of Mrs Berg. The motivation for finding out more specifically what has made Mrs. Berg younger and younger is followed by the visual expectation built up through the compère's glances. These glances also anchor, in time and space, the coming story about The Modern Kitchen where Mrs. Berg is the key figure. Mrs. Berg is in the universe of the film - Per Aabel's neighbour. The Modern Kitchen that so radically and miraculously changed Mrs. Berg and her family is granted greater authenticity and credibility through the compère's gaze.

\section{The First Compère from the Perspective of the History of Film}

This direct address to the spectator is related to both the film producers' understanding of housewives as a target audience, and their approach to audiovisual communication. I will continue to consider this personal, intimate communication in light of the contemporary cultural and the media landscape.

\section{- The Housewife Films as Enlightenment}

As previously mentioned, Housewife films are part of a larger contemporary project of Enlightenment of the people. The Housewife film Slik kan det gjøres is described on the 
certificate of censorship as an "educational film for housewives," despite the fact that the film was financed by companies who wanted to sell their products to consumers and was, as such, a commercial. Producers of Housewife films would point to the Housewife film not as a commercial. ${ }^{13}$ The individual informative commercial in the Housewife film was too long to function as a regular commercial connected to feature film screenings. The Norwegian Board of film censorship may have chosen this label because instructive educational films for housewives had been produced for several years. In the 1950s, housewives were an important target group, not only for producers of goods, but also for educational parties such as government services and private organizations. These films could and were called housewife films. The common denominators for all these films were education and information.

Within public administration, the education of housewives was a priority. Statens opplysningskontor $i$ husstell (The National Information Bureau for Domestic Science) had been established in 1940 and was responsible for the production of films, slide shows and brochures dealing with housework and cooking. The information bureau's films were used by home schools and agricultural companies, and by the Statens veiledningstjeneste $i$ heimstell (National Advisory Service for Domestic Science). ${ }^{14}$ Closely related to governmental housewife information programmes were the Norwegian Broadcasting Corporation's (NRK) housewife programmes. Hans Fredrik Dahl describes the radio show Husmortimen (The Housewife Hour) along with Landbrukshalvtimen (The Agricultural Half Hour) as "lectures with strong educational characteristics" (Dahl 1999a:94). The housewife radio programmes were probably moderated following developments in programme policy, but hardly to the extent that they could have inspired the intimacy of the Housewife films' compère. However, we do know that these programmes were so popular that when the NRK began broadcasting Norwegian parliamentary debates in 1963, representatives who wanted to speak to the radio audience avoided speaking during the housewife programmes (Dahl et al. 1999:335). It is an interesting fact of political rhetoric that former Norwegian Prime Minister Einar Gerhardsen emerged as genuine and authentic in his radio speeches in the $1950 \mathrm{~s}$ - primarily by adjusting his voice to the medium. Anders Johansen, in his study of broadcasting and political speech, points out that Gerhardsen could be regarded as "the first Norwegian politician who, to the entire nation, "truly was himself'” (Johansen 2002:101).

When NRK's television branch started its test broadcasting in 1954, one of the test programmes was a Housewife Hour (Totland 2001). This programme is not found on the programme list when the test period ended in 1960. The fact that NRK abandons the term "housewife" as a prefix in its programme titles could signal NRK's renewed goal to address the whole family and the entire nation. However, subject areas from the housewife programmes were now carried forward in gender neutral terms in programmes like the cooking show Fjernsynskjøkkenet and varied consumer programmes.

In addition to the publicly produced housewife information, organizations such as Husmorforbundet (The Housewife Society) and Norske Kvinners Sanitetsforening NKS (Norwegian Women's Hygiene Society) produced films as a part of their members' education. For example, Ingerid Askevold, technical consultant for Slik kan det gjøres, reported in an interview with the film magazine Filmjournalen (The Film Journal) just after World War II that she had "produced films since 1937." At the time of the interview, she was the head of the National Information Bureau for Domestic Science, but she produced her first film for the NKS - dealing with care of infants - and 20 similar films 
before 1946 (Filmjournalen no 8/1946). The NKS's films were part of the organization's education in nutrition, hygiene and conscious consumption.

Industry and commerce realized that the women's organizations could be important allies in reaching housewives as consumers. During the depression in the 1930s, the Housewife Society had supported Norwegian industry by encouraging housewives to choose Norwegian products. The industry responded by financing the Housewife Society's educational activities (Melby 1995: 350). In other words, when it comes to housewives, marketing and education were connected long before the industry's joint advertising, the Housewife film, emerged.

Product advertising and educational information existed in both private and public housewife education outside of the Housewife films. Could the hosts of these films exhibit the same type of intimate communication as Per Aabel's compère? Information and educational films were, to a large extent, characterized by direct address. The instructors, or lecturers, in educational films speak to and with the audience. Still, it is hard to find examples of educational film instructors who, to the degree of the housewife film's compère, make friends with, have dialogues with, and even flirt with their audience. Housewife films were an extension of travelling public and private lecturing and educational activities, but not even these activities were likely to exhibit the same intimate nature as the Housewife film.

\section{- Housewife Films, Travel Films, and Newsreels}

However, the gradual increase in focus on the main character and narrator/filmmaker within the documentary in the 1950 s can be historically traced. In his examination of Norwegian documentaries, Gunnar Iversen points out that Kon-Tiki (1950) introduced a shift to more personal, experience-oriented travel descriptions. Through his opening lecture and his commentary on the sound track, the Norwegian scientist and filmmaker, Thor Heyerdahl, places himself in the role of personal on-screen narrator making the film differ from the "down-to-earth reports at a distance" that emerged during the inter-war period (Iversen 2001: 87). This tendency is even more evident in Per Høst and Rasmus Breistein's expedition and travel films from the 1950s where they present themselves talking with "the natives" (2000:88-93). However, new technology for synchronous sound-on-film recording allowed the interview-based on-location documentaries to emerge during the second half of the 1950s.

The cinema audience is familiar with the engaging, yet not personal, style from the newsreels' characteristic voice-over. Within this news journalism, the voice-over is not in focus as persona, but men like Rolv Kirkvaag and Jan Frydenlund became legendary through their emotional and personal style of speech. They represented a contrast to the more distanced mode of NRK's news journalism on radio and television. The aesthetics of the newsreels, particularly the way in which two involved, enthusiastic commentators exchange turns on the sound track, are also found in several Housewife film commercials and in the engaged presence of the compère.

\section{- Housewife Films and the Codes of Advertising}

Examples of synchronous audiovisual communication exhibiting direct eye-contact with the audience are found in the educational film's lecturing, but primarily in commercials. For example, in her account of the history of Norwegian commercials, Kathrine Skretting describes a commercial for the PP pastille from 1957 arranged as a conversation in the 
studio between the radio celebrity Rolv Kirkvaag and actress Ingerid Vardund. Kirkvaag speaks directly to the camera and states, "Ladies and gentlemen. ..." He then converses with Vardund about the pastille's excellence, finishing off by speaking directly into the camera, and urging the audience to buy the pastilles. Kirkvaag is down-to-earth and formal, and fills the role of a charming host, while still maintaining a distanced professionalism. Skretting uses this film as an example of how the short commercials of the $1950 \mathrm{~s}$ focused on the product, hoping to persuade the consumers with rational arguments: "The tradition from the inter-war period of several minutes of entertaining and fun at first and the advertising information at the very end, is over" (Skretting 1995:131). Kirkvaag's communication resembles the style of the formal lecturer rather than the intimate and personal nature of Per Aabel. Nevertheless, the PP pastille commercial follows the inter-war period commercials by using nationally recognized actors made famous through film, radio and the weekly tabloid press. At this point, both the contemporary and the inter-war period commercials are connected to the Housewife films. It is, at the same time, evident that Housewife films with their longer format follow the commercial ethos of the inter-war period, and differ from contemporary methods, by emphasizing entertainment and fun.

As Housewife films are part of the commercial film tradition, this particularly applies to commercials for food, detergents and household appliances that, since the end of the 1920 s, had been explicitly targeted towards married women. Lilleborg's marketing campaign to launch the detergent Blenda in 1932 illustrates that their strategy included more than traditional commercials directed towards housewives. A long commercial was produced, and special buses were equipped with film projectors and anything else required to demonstrate washing methods live. These buses visited housewives all over the country with their films and demonstrations. The Blenda commercial was screened together with film comedies to attract the audience (Iversen 1999:22). Market surveys initiated by Sverdrup Dahl A/S apparently concluded that the short commercial film format was inadequate for marketing household technology (Hartviksen 2001). It could be argued that the informative aspect found in all advertising in the Housewife films was emphasized to such a degree that these films rhetorically transgressed the commercial film format (Jhally 1987: 24pp).

\section{Conclusion}

The aspects of the Housewife films communication, displayed in the style of the first film's compère, are reclaimed in various genres of contemporary films. However, the compère's intimacy and lack of formality emerges as characteristic and innovative with regard to the film language in general in the early 1950s. The compère in his armchair has more in common with the personal, direct and inviting style now primarily associated with modern television aesthetics. It is easy to draw parallels to Per Aabel's compère when reading, for example, Graeme Burton's description of famous TV hosts and their way of approaching their viewers:

When David Attenborough whispers his comments about the wildlife that his cameraperson is close to, he is drawing us into the situation, making believe that we are there with him, in some far-away location. We become co-conspirators in his adventure. Noel Edmonds had done the same thing on his House Party show, when he mugs to the camera and/or beckons us through it to come to the door with him, or to enter someone's home through a previously concealed camera. 
This sense of relationship, of closeness, of subjectivity, is strong on television. So often the face stares at us from the screen, addressing us, inviting us, (and) sometimes challenging us. (Burton 2000:102).

An interesting parallel to the Housewife films can also be found in the contemporary, commercial TV's consumer magazines that are modelled after weekly newspapers' mix of entertainment and information. Compared with two very popular shows from American TV in the 1940s and 50s, the programme formats were described as "hyper-consumerist" and as "(...) a hybrid of the magazine program, one that incorporated entertainment, celebrity guests, 'expert' service talk, and musical numbers alongside home economics material" (Cassidy and White 2002:41). The TV hosts for these popular daytime shows were women who emphasized the importance of appearing as housewives and who did not talk down to their main audience of housewives.

The housewife films' compère illustrates that this type of film similarly talks to - and not just down to - housewives. Contemporary international commercial television could have been a source of inspiration. ${ }^{15}$ In a nation with public service broadcasting like Norway, Housewife films emerged as an alternative to those branches of the trading industries that would otherwise use daytime broadcasting to reach the housewife as consumer. The Housewife film may in this respect be understood as the counterpart to commercial daytime television, both financially and with regards to the host's direct and intimate address.

\section{Notes}

1. The research project 'Between Market Economy and Demographic Politics: Housework as Ideology and Practice' is led by professor Gro Hagemann, Historian at the University of Oslo. The project analyses the public discourse on housework and its importance for the social construction of gender during the previous century.

2. Arnfinn B. Storkaas, General Manager of Informasjonsfilm, personal telephone interview, 3 May 2001.

3. Se Hartviksen, Ivar 1995. As a result of this communication Starfilm A/S was established in Oslo in 1952 as a subsidiary to the Swedish Star Studio, in order to produce Housewife films.

4. The housewife films radically differ from their "sister" programmes, soap operas, in the absence of pathos - the appeal to strong emotions. Logos, the appeal through structured argumentation based on sense, is more apparent, but in the entertaining breaks between commercials, it is subordinate to the ethos appeal.

5. So far in my work, I have had the opportunity to watch 15 of the 28 films - complete or in excerpt. The ongoing project partially finances video scanning of copies - too damaged to screen - held by the Norwegian Film Institute in Oslo.

6. Ingrid Espelid, later Espelid Hovig, can be regarded as an icon within Norwegian culture and society after leading the cooking programme NRK Fjernsynskjøkkenet (The Television Kitchen) for 30 years.

7. Düring directed a long series of short films and eight feature films. During the $1950 \mathrm{~s}$, he was a part of an artistically ambitious film society $A B C$ film, and also directed two feature films in the 1970s for the modernist Erik Løchen (Iversen 1992).

8. The term "compère" is taken from the films' titles.

9. The Aabel quotations are translated from Norwegian into English by Randi Gamlemshaug.

10. For an introduction to, and discussion of, classical rhetoric refer to Andersen 1995 and Kjeldsen 2002.

11. In his history of documentaries, Bjørn Sørenssen uses the term "mediating body" to characterize how the television, through its journalistic connection, would differ from the documentary mode at this time of history (Sørenssen 2002:223).

12. This is the title of a Norwegian fairy tale about a man who had the idea that his wife never did enough in the house. His wife asks him to exchange jobs for one day. She does well out in the fields, but the husband is a total failure in the house and the fairly tale communicates this with considerable comic detail and a twist. 
13. Terje Helweg, Informasjonsfilm, personal interview, 23 October 2001. Helweg emphasized how producing Housewife films was even less prestigious in contemporary Norwegian film milieu than producing commercials.

14. The service had been established in 1937 as an educational organization intended for housewives, with branches in county and city municipalities, belonging to the Ministry of Agriculture up until 1959. In 1969, the information bureau merged with other government institutions and adopted the name Statens institutt for forbruksforskning (National Institute for Consumer Research).

15. Knut-Jørgen Erichsen, manager of Starfilm A/S, the first company to produce Housewife films for the Norwegian market, did not only win the first Annonsørenes Oscar (The Norwegian Advertisers' Oscar) for best commercial in 1950, but he also had a background as a commentator on the newsreel and had worked for the NRK from 1945 to 1949. Jørgensen was, in the 1950s, one of the advocates in favour of commercial television in Norway.

\section{References}

Andersen, Øivind (1995) I retorikkens hage. [In the Garden of Rhetoric.] Oslo: Universitetsforlaget.

Bastiansen, Henrik G. \& Meland, Øystein (2001) Fra Eidsvoll til Marienlyst. Studier i norske mediers historie fra Grunnloven til TV-alderen. [From Eidsvoll to Marienlyst. Studies in the History of Norwegian Media from the Constitution to the TV Age.] Kristiansand: Høyskoleforlaget.

Brinch, Sara \& Iversen, Gunnar (2001) Virkelighetsbilder. Norsk dokumentarfilm gjennom 100 år. [Reality Images. A Century of Norwegian Documentaries.] Oslo: Universitetsforlaget.

Block, Eva (1996) (ed.) Husmors filmer. Dokumentation från forskarsymposium. [Housewife films. Documentation from a Research Symposium.] The Swedish Sound and Image Stockholm: Archive.

Burton, Graeme (2000) Talking Television. London: Arnold.

Cassidy, Marsha and White, Mimi (2002) Innovating Women's Television in Local and National Networks: Ruth Lyons and Arlene Fransis, Camera Obscura 51, vol.17, no 3.

Dahl, Hans Fredrik (1999a) Hallo, Hallo! Kringkastingen i Norge 1920-1940. [Hello, Hello! Broadcasting in Norway 1920-1949.] Oslo: Cappelen.

Dahl, Hans Fredrik et al. (1999) Over til Oslo. NRK som monopol 1945-1981. [Over to Oslo. The NRK as a monopoly 1945-1981.] Oslo: Cappelen.

Hartviksen, Ivar (1995) Historien om Centralfilm - storprodusent av reklame, Rush-print nr.2/95, del 1.

Hartviksen, Ivar (2001) Reklamefilmen i Norge - etter 1945. [Commercials in Norway - after 1945] Unpublished script.

Iversen, Gunnar (1992) Framtidsdrøm og filmlek. Erik Løchens filmproduksjon og filmestetikk. [Dreams of the Future and Playing with Films. Erik Løchen's Film Production and Film Aesthetics.] University of Stockholm: Department of Theatre Studies. (Diss.)

Iversen, Gunnar (1999) Modernitetens budbringere - Om de norske husmorfilmene. [Messengers of Modernity - About the Norwegian Housewife films.] in Myrstad, Anne Marit \& Slottemo, Hilde Gunn (1999) "Slik kan det gjøres" Flerfaglige blikk på 'Husmorfilmen'. Trondheim: Norwegian University of Science and Technology, Department of Interdisciplinary Cultural Studies, Centre for Women's Studies. (Working paper 1/1999)

Iversen, Gunnar (2001) Fra reportasje til sosialpoesi. - Hundre års norsk dokumentarfilmhistorie. [From Reports to Social Poetry. - A Century of Norwegian Documentary History.] in Brinch, Sara \& Iversen, Gunnar (2001) Virkelighetsbilder. Norsk dokumentarfilm gjennom 100 år. Oslo: Universitetsforlaget.

Jansson, Puck (1996) Om produktionen av husmorsfilmerna, lite historik. Refrat av frågestund. [On the Production of the Housewife films - its History in Brief. Summary of a Question Time.] in Block, Eva (1996) (ed.) Husmors filmer. Dokumentation från forskarsymposium. The Swedish Sound and Image Stockholm: Archive.

Johansen, Anders (2002) Talerens troverdighet. Tekniske og kulturelle betingelser for politisk Retorikk. [The Speaker's Credibility. Technical and Cultural Conditions for Political Rhetoric.] Oslo: Universitetsforlaget.

Kjeldsen, Jens (2002) Visuell retorik. [Visual Rhetoric.) University of Bergen: Department of Media Studies. (Diss.)

Melby, Kari (1995) Kvinnelighetens strategier. Norges Husmorforbund 1915 -1940 og Norges Larerinneforbund 1912-1940. [Female Strategies. The Norwegian Housewife Society 1915-1940 and The Norwegian Association for Female Teachers 1912-1940.] Trondheim: Norwegian University of Science and Technology. (Diss.) 
Myrstad, Anne Marit \& Slottemo, Hilde Gunn (1999) "Slik kan det gjøres” Flerfaglige blikk på 'Husmorfilmen' ["That's How To Do It" Interdisciplinary Look at the Housewife Films] Trondheim: Norwegian University of Science and Technology, Department of Interdisciplinary Cultural Studies, Centre for Women's Studies. (Working paper 1/1999)

Skretting, Kathrine (1995) Reklamefilm. Norsk reklame i levende bilder 1920-1990 [Commercials. Norwegian Commercials in Vivid Images 1920-1990] Oslo: Universitetsforlaget.

Sørenssen, Bjørn (2001) A fange virkeligheten. Dokumentarfilmens århundre. [Capturing Reality. The Century of the Documentaries.] Oslo: Universitetsforlaget.

Totland, Geir (2001) “Fjernsynet før fjernsynet, NRKs prøvesendinger $1954-1960$ ”. [Television before the Television, the NRK's Test Broadcasts 1954-1960] in Bastiansen, Henrik G. \& Meland, Øystein (2001) Fra Eidsvoll til Marienlyst. Studier i norske mediers historie fra Grunnloven til TV-alderen. Kristiansand: Høyskoleforlaget. 